\title{
Theme Centered Interaction in Critical Vocational Teacher Education: An Introduction Into an Ethical Founded Method and Model to Strengthen Self-reflexive Autonomy and Socially Responsible Action
}

\author{
Franz Kaiser* \\ University of Rostock, Institute for Vocational Education, \\ August-Bebel-Str. 28, 18055 Rostock, Germany
}

Received: 15.05.2018; Accepted: 21.08.2018; Published: 22.11.2018

\begin{abstract}
Context: The train of thoughts in this contribution is situated in the VET teacher training on an academic level, as it is usual in Germany. Key issue is the pedagogical qualification of the VET teachers and the question of how to give them possibilities to reflect their own biography, their interdependences to the actual cultural and economic environment and their way to choose the pathway to become a VET teacher. How to enable them to argue with their values, fears, strength and weaknesses in their life and especially in leading groups, as they will have to do in classroom management. And at least how to give them an idea of an emancipative, critical and participative way of forming learning situations in which they feel sure and lively to encourage the apprentices and learners in schools to act autonomic and critical in work and besides. This is necessary because of the changes in work and VET in the recent centuries with consequences for workers, learners and curricula as well as the contradictions in that process.
\end{abstract}

${ }^{*}$ Corresponding author: Franz.kaiser@uni-rostock.de

ISSN: 2197-8646

http://www.ijrvet.net 
Approach: The transformation and the liberalisation of markets and changes of work organisation, the enlargement of tasks in the occupations adds greater meaning to social knowledge and competences, the ability for teamwork and personal development in vocational education. To develop this ability Theme-Centered Interaction (TCI), as a humanistic-psychological approach is used and combined with Critical-Subject-Oriented Vocational Education Theory, inspired by the Critical Theory of the Frankfurt School. VET-teacher students learn in theory and practice to shape their own way to lead themselves and the pupils in the class and to reflect their activities in a critical way of thinking. The paper ends with brief description of seminar lectures with VET teacher students at the University of Rostock where TCI is practiced as one example how we can reach the objectives described before.

Findings: The TCI-concept is helpful to set up better teamwork and self-reflection in the group of the learners. Its a useful way to prepare them for their practical school phase in which TCI is used as reflection model as well.

Key Message: Universities as learning places in the tradition of enlightenment have to open up spaces in VET teacher development for domination-free communication and participatory learning within the framework of university studies, which can create a distance to a given social reality, enables students to dissociate from collectively developed goals to become critical formers of their working life and teaching.

Keywords: VET, Vocational Education and Training, Vocational Teacher Students, Communication Skill, Critical Thinking Skill, Interpersonal Competence, Curriculum Development

\section{From "We do what we're Told" to the "Human Centred Factory"}

In the tradition of medieval crafts it was common that the journeyman usually followed the rules of the handcraft masters. They were not allowed to invent new ways of producing or new products. It was a question of protecting the market, preventing rivalry and at least stabilize the domination of the masters to hinder innovation and autonomous decisions of the journeymen (Stratmann, 1993). In midth of the $19^{\text {th }}$ century the journeyman start to realize the different interests of them and the masters and started to organize their own associations.

Karl Marx analysed during that period the situation of the workers in the industry and pointed out that they are losing the essential meaning of human work because of disaffection (Marx, 1962). Because of the process of increasing of division of labour and the automatization the workers lose more and more the freedom to make their own decisions in work and started to be an appendix of the machines in following the orders of the capitalists. But it get more and more normal that the owner of the company is allowed to fix the rules of work, and that losing the right to act as a free human during working time and following in blind obedient the order of the owner of production resources. Getting the strength back to the workers the unions tried to protect the 
workers more and more from inhuman work environments. In most cases it ends with collective bargaining including some agreements on health protection and holidays. In the early 1970s the German Unions began to call for humanisation of work and started some projects and research on that topic (Vetter, 1973) In that time German Unions described the aims of humanisation as follows: "What is new, however, is that the diverse aspects of the conditions of work, which have hitherto been dealt with more or less piecemeal, are now seen as part of a large whole embracing related matters such as the organisation of work (i.e. of the production process itself), hierarchical structures, relation with workmates, the social situation within the firm, the working environment, participation in decision-making at all levels, and opportunities for self-development and advancement" (Engelen-Kefer, 1976, p. 227). But this became very rarely reality and in only a very few companies workers were involved in decision making on all level or reached participation in profit (Schapfel-Kaiser, 2005). But Englen-Kefer described what humanisation really could mean.

It was in 1995 when Petersen and Rauner published a paper, titled: "Education and training for the human centred factory"that was inspired by the famous MIT study about lean production. The hope was, that the projects in the late 1970th who dealt with humanization against routine work and towards job enlargement would be continued and supported by the new production strategies and changes in work organisation. The "modern work environment" with team production, decentralised quality assurance and co-consideration would help to enlarge qualifications, open space for shaping technic and work. But, as we know now, this happens only in a few cases. In most of the companies with lower co-determination by trade unions and works councils, it leads to more time pressure for the workers, flexibility that only takes the need of the organisation in count without real benefit, rather they "earn" more health damage from a psychological point of view (Schröder, 2009; Kaiser, 2008).

Nevertheless, it should also be noted that the qualifications in the training regulations have changed and have certainly taken up the changes in working life to the greater importance of social competence as a key competence (Streumer \& Bjorkquist, 1998). This happens in Germany long before the debate has started about the implementation of EQF and National Qualification frameworks with their three / four descriptors: Knowledge, skills and competence (Europaen Commission, 2008) ${ }^{\mathbb{1}}$. This change is also of special significance for the qualification of in-company and school-based training employees. Their workconcept changes; from leaders to learning guides. "As already described, the trend from teaching to learning creates a need to change the practices of VET teachers who have traditionally worked alone and concentrated on disseminating knowledge to trainees. Today, teachers need to work in teams, they have to be able to guide trainees more than just transfer knowledge, and they must also be able to plan, describe and reflect on their own teaching practices (Cort, Härkönen, \& Volmari, 2004, p. 20). Theme-centered interaction (TCI) as a systematic qualification method for trainers in companies can then also be found sporadically in recent times (WILL-Schweiz, 2004).

\footnotetext{
1 “... in the German-speaking countries, the common differentiation is between Fachkompetenz, Methodenkompetenz, Personalkompetenz and Sozialkompetenz; while in the English-speaking countries, the conventional categorisation is between 'cognitive competence', 'functional competence' and 'social competence'." (European Commission 2008, p. 5)
} 


\section{Bildung in the Tradition of the Critical Theory of Frankfurt School as an Indivisibility Part of Vocational Education}

Vocational training is responsible for the transition of young people from the education system to the economic system. In an economic system that follows the primacy of maximisation of profits, vocational training focuses on the usefulness of the qualified worker. Governments and the commission of the EU are measuring the success of a VET system by the successful transition from school to the labour market. In contrast, the claim to Bildung, in the sense of human self-empowerment and the ability to participate comprehensively in shaping social and individual relationships, takes a back seat in measuring the success of a VET system as part of national education systems.

There always had been a tension between vocational and general education. The contradiction between integrating Bildung, in the spirit of enlightenment into the existing system and at the same time empowering people to lead their own lives in a fair life has been made already clear in the early bourgeois concept of Bildung (Koneffke, 1987) and in vocational training (Kaiser, 2016). This contradiction of Bildung that is oriented on an economic system that works on categories as "faster", "bigger" and "more" to appreciation of balance and thoroughness was a part of Max Horkheimers (a philosopher of critical theory from Frankfurt school) ideas in the $1950^{\text {th }}$ inspired by the crucial experience of the Nazi era. "The process of Bildung has turned into that of processing. The processing - and this is the essence of the difference - leaves the object no time. But time stands for love; to the thing to which I give time, I also give love; violence is quick" (Horkheimer, 1952, p. 166).

The preparation of individuals for assuming a specialised social function through qualification; the purpose-oriented acquisition of skills, abilities and knowledge, as it is called in the jargon of the Vocational Training Act in Germany, appears to be a necessary prerequisite for efficient work processes in the complex organisation of our increasingly networked societies. The question of the breadth, depth and orientation of this preparation is that of Bildung par excellence and thus also a central question of vocational training.

When Horkheimer, in 1952 and 1953, addressed to students, compares the process of Bildung with that of processing and speaks of the development of technical skills and the accumulation of objectified information, he does not refer to vocational education but to the study that was in store for those present at the time. The emphatic appeal of taking time to get to the heart of things and to find out what is at the heart of them is as true then as it is now, but may perhaps seem almost ignorant of the realities of the Bologna reform era. He is an impertinence in the best sense of encouragement.

Does this older quote perhaps show that, in the present circumstances, academic and general education is closer to vocational training than it claims of itself? Conversely, has vocational training possibly moved a long way from the bondage education as which it identifies Heydorn and many other general educators?

"The formation of the concept, the formation of consciousness in the strict sense, falls to the rulers, so that the possibility of disposal over the empirically given, the 
freer movement in time and space; the formation of the servant remains bound to the materials, it is labour (Heydorn, 1973, p. 270).

Heydorn distinguishes the formation of servant and master by the possibility to detach oneself from the directly given object by means of Bildung, to think about it and to shape the conditions in one's own sense. On the other hand, the servant follows unthinkingly the demands for work, in the sense of manual labor. However, the further development of work in times of digitalisation and modern vocational education and training, combined with the reduction in the number of occupations, the increasing systematisation of knowledge stocks and the associated broadening of the knowledge and skills to be acquired in initial and continuing training, has now led to a significant expansion, which speaks at least partially against the "slavery" approach of education to a compliant workforce. Whether it is as close to what Heydorn addressed with awareness raising and whose lack he already complained about in the general education system remains just as doubtful as the question whether it is the subject of general education today.

The indivisibility of Bildung demanded in the 1970s and especially in the tradition of critical education theory is a demand for vocational and general education equally; it is formulated only rarely in vocational pedagogy. Connected with it is the possibility for everyone to develop critical self-confidence (Paffrath, 1992) and the ability to relate individually to things and to oneself and to develop utopias that go beyond the present.

"From the forces of intellectual and ethical resistance, the utopian capacity drains as an indigenous, but always first to be released. According to Heydorn, this personal interpersonal encouragement is needed so that the idea of freedom can be experienced sensually in the ideal of free struggle and calls for a continuation in solidarity. When it happens, the utopian ability is at the same time instigated to begin its obliging visualization" (Gamm, 1983, p. 173).

Due to its indivisibility in all fields of pedagogical work, the task of Bildung and in consequence vocational education, is to incite people to think beyond the present, to think together out of the reflection of human history and to practically develop it further with the help of utopian images.

This should have consequences for the VET teacher education in the study programmes at universities. They have to enable students to develop their own vision of how is the shape of a good vocational education. That means to encourage the teacher students to reflect the social processes, the phenomena of inequality in the selection processes of schools and private apprenticeship contracts as well as the contradictions of vocational education embedded in a capitalistic economy. "Enriched in historical reality, Bildung remains an achievement of abstraction; only society, brought to its full abstraction, enables it to recognize the richness behind bars, the fullness into which human can enter" (Heydorn, 1970, p. 27). So, the analyse of the historical shaping of the national VET-system as a bridge between educational system and labour market has to be enlighted to get in touch with role of the different interests of union, employers and government and the changes that happened because of political, cultural and technological changes in the society.

At the same time, we should be aware, that learning is minimum as strong influenced by the learning form as by the curricula of learning. That means, if we want to de- 
velop the teacher students skills to shape the changes of vocational education, and they should be able to do so as professionalized agents in that system, we have to develop their skills to create a democratic, participative form of learning situations. Based on that considerations, we implemented at the University of Rostock besides courses on theoretical reflexions of different paradigms of pedagogics, training their argumentation and theoretical reflexion skills, specific vocational training methods as work based learning, project learning and guided experiences in the schools and other learning places of VET a seminar on Theme-Centered Interaction (TCI) with two main aims:

1. Critical reflection on the own biography, experiences of teaching and learning to get a critical point of view on the own behaviour and mentality. To get more emancipative from the unconscious influence factors.

2. Getting in touch with an utopian idea and practice of participative, creative way of teaching and learning that encourages the learners to take a more important part in the development of the learning process, to allow them to take time in self-reflexion and to get an experience of the power of a learning group when a culture of authentic participation and team oriented work has been developed.

The following part of the contribution shows why TCI has been chosen, where the parallel roots to critical theory are and why it helps to strength skills for vocational education in a democratic society.

\section{3 "To Know that Everybody Counts - Against the Social Coldness" - History and Concept of TCI in a Nutshell}

\subsection{TCI as a Descendant of Psychoanalysis and Reaction on the Nazi Regime}

TCI is both a research method, a pedagogical method and a psychological theory (Schapfel-Kaiser 1997). It has its roots in the psychoanalysis in which its founder Ruth Cohn was trained. From her involvement with humanistic psychology she developed the form of therapy into a pedagogical approach which, as the practice progresses, wants to enable the participants to become more and more aware of their inner resistance on the one hand and to take responsibility for their own actions with regard to themselves and the rest on the other. Cohn expressed this idea in a little poem I picked up on in the title of chapter 3 :

\footnotetext{
"Knowing we count

with our life

with our beloved

against the cold
}

For me, for you, for our world" (Cohn, 1990, p. 2). 
In doing so, she takes Harry Sullivan's further development of Freud's approach to an interpersonal relationship theory and leaves the therapist's distanced attitude, transforming the therapist of a group into the role of the participating group leadership. "The experiences gathered in psychoanalytic groups, namely, that it is possible to create an atmosphere of trust by demanding authenticity and an open and responsible exchange of feelings, led Ruth Cohn to conclude that these phenomena should be introduced and pursued as well in nontherapeutic groups. TCI, with its principles of group education, is the attempt to create just these conditions that enable trustful cooperation" (Rubner, 2017 , p. 32). But the emergence of the TCI and the significance of values associated with it points to other sources ranging from French existentialism and American pragmatism to Ruth Cohn's own life story. A quote from Satre can underline the link to existentialistic philosophy: "And if we say that human beings are responsible for themselves, then we are not intimating that humans are responsible only for their own individuality, but rather that they are responsible for all other human beings" (Sartre, 1961, p. 12, quoted from Zitterbarth, 2017, p. 46).

It was during the Nazi era, when Ruth C. Cohn, a Jewish woman, born 1912 in Berlin flew first to Switzerland, where she started studying psychanalysis and moved some years later in the USA to complete her therapeutic education. She lost nearly her whole family in the Nazi concentration camps. In contact with some therapists in the tradition of humanistic psychology as Carl Rogers, Virginia Satyr and Fritz Pearls and influenced by the intellectuals in Europe and their discourse about the theory of Karl Marx and the existentialism from Jean Paul Satre and her own experiences she developed her own theory. "TCI is very much influenced by psychoanalysis and also very much influenced by the historical situation of national socialism" (Cohn, 1992, p. 317).

The emancipation from the dogmatic psychoanalytic schools since the 1950s came from the perception that the couch is too small to meet the many problems of mankind and to open up as a therapist for people who would not seek therapy. The finding that we live in a sick society, as shared by Erich Fromm and other social scientists associated with critical theory and psychoanalysis, shows TCI's connection to the critical theory of the Frankfurt School. And so it is that many of us, for part of the working day, leave our little couch-centered offices and chair-circled rooms to meet with people anywhere outside in the school's faculty room, at conference tables, in classrooms, in social or political meeting places, at the bank president's luncheon table, in the workman's cafeteria, or wherever groups of people work or live together or wish to develop their capacities in similar directions. We have come to realize that frustrations and hatred need not destroy, but can be lived with, integrated and used. We have learned to assist in opening doors to constructive and creative living. We take our tool kits with us on the road. We hope to win the race against unnecessary decay and global death by social action" (Cohn, 1969, p. 2). During the following years TCI was developed as a group-pedagogical method and theory, first used in workshops of psychotherapists and later used in many contexts, as Cohn described in the quote. When Ruth Cohn moved back to Europe, Germany and Switzerland in the 1974 TCI spread in the German-speaking world. The training institute WILL (Workshop Institute for Living Learning) was founded and many people were trained to practice TCI in schools, apprenticeship, training leadership, pastoral 
care and psychotherapy and supervision. The subsequent remarks will give a short inside in the basic modell. The actual translated Handbook of TCI provides deeper insides (Schneider-Landloff et al., 2017).

\subsection{The Model of TCI}

The TCI's four-factor model is the central model for designing and analysing events in groups, regardless of whether they are being taught or meeting.

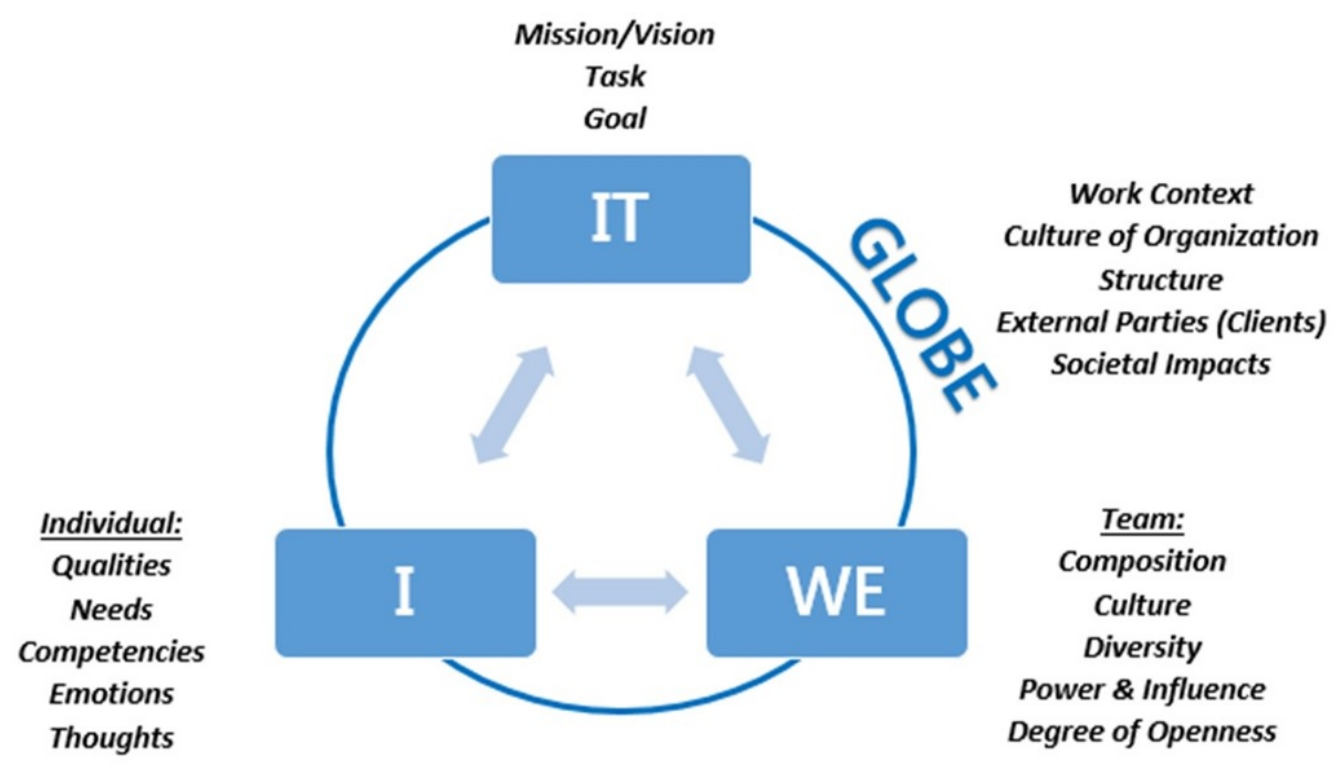

Figure 1: The Triangle in the Circle

In most professional contexts, encounters and forms of learning take place that leave no room for encounters with the subconscious. The reflection and visualization of the urges and needs that exist in the respective individual and between the members of the working group are pushed into the realm of taboos. The part covered (tabooed) by water of the iceberg, described by Freud thus, has an effect and threatens to stand in the way of humane and authentic cooperation.

Therefore the reflection on one's own (I) self stands at the beginning of a meeting of group members. Although it is always taken into consideration that the individual's becoming is subject to social and historical restrictions (it comes from external conditions, some of which have become difficult to change), the challenge: "Be yourself" remains a central starting point and goal. "Only I and no one else can experience and represent my perceptions, ideas, feelings and thoughts for me, no one but me has my memories and desires and decides for me" (Matzdorf \& Cohn, 1992, p. 71). The independent creation of my own image about experiencing and becoming aware of images of myself and others is encouraged by "...the way to the ancestors and the way to the others around me" (Langmaack, 1991, p. 41). 
From an anthropological point of view, man proves to be deeply related to others and referred to them. The group (We) that we open the self-centered person for the world and the world for him. "At the border, encounter is possible. We develop our selfexistence in the other person. On you, man becomes I, as Martin Buber says" (Amann, 1993, p. 158). The integration of the individual in the formation of a group requires respectful treatment, which does not require submission but an effort for authentic participation in one another. "It is a love- and relationship-capable ego that constitutes the vision of theme-centered interaction, and not an ego that revolves only around itself and is dominated by the desire for self-awareness and self-development (Kroeger, 1993, p. 103). In order to enable the subjects involved to develop into the I, the group members must experience and respect themselves as complement and background, as independent subjects, whose blind classification in the group always results in a loss for the same, while the preservation of difference contributes to the strength of the group. "In my search for such elements I noticed that the liveliness of group therapeutic learning has to do above all with a respectful attitude towards the emotional world and the personal state of the individual. The group is personally involved when one of the participants speaks of himself; it takes his violent palpitations, his heavy breathing, his tears and his joys as important. Emotions are respected as man's very own right - regardless of whether they are realistic or represent an illusion"(Cohn \& Farau, 1984, p. 112).

The topics (It) serve orientation in a concrete situation. They are the central reference and challenge arising from the objectifiable phenomena and their demands on the group. Topics arise from the common interests of the participants (saving energy in private households; designing theoretical lessons at vocational school, getting out of individual traffic...), the tasks required from institutional contexts (joint planning of the distribution of tasks of an institute, a working group...) or from individual conflict situations of the participants, which may lie outside the context, or may relate to other group members, which concern common structural finding or similar. The topics thus serve to define a manageable common task and to open up the context to the outside world. "When the subject, the task, is wanted and supported by all the ego as a concern of its own and in relation to one another, there is an optimal work situation (Matzdorf \& Cohn, 1993, p. 72). The process of the group itself can become an issue, because resistance to other issues can only be overcome by clarifying the emotional aspects within the group.

The Globe stands for the environment, the external influences to which the group is exposed, it sets the limits and is at the same time the real place in which the group members act. Only a realistic knowledge of the Globe will qualify individual perspectives. It is the link between subjective experiences and objective circumstances - is at the same time the starting point and goal of the TCI conditioned by the recognition of the individual interdependence of the individual subjects in the global context of life. "In dealing with the Globe, the TZI shows its relevance to everyday life. What is a matter of course in individual therapy also applies here: Bringing the participants out of their Globe into the group events or into another project and leading them to the end" (Langmaack, 1991, p. 74). The weighting of the influences of the Globe are certainly different at each meeting of the group, depend on the general events of the day, and those that affect the individual participants depend on the different interests and perspectives 
of the participants, their life contexts. Taking these influences into account, or taking them up facilitates the understanding of the leaders for the situation of the group, and sensitizes the group to itself and its environment.

Between the four elements of the structural model of theme-centered interaction there is a dynamic in the process, which leads to an over- and underemphasis of the individual elements. This means, for example, that massive personal disturbances can lead to neglect of the topic, as well as lustful group-dynamic exercises and experiences contribute to the lack of consideration of the Globe. The goal of designing educational processes with the help of the TCI and thus an essential task of the managers is to maintain balance. However, this cannot be done by the leaders alone. All participants are encouraged to lead themselves and to give priority to disturbances.

\section{The Implementation of TCI in the Study Programme of VET Teachers}

\subsection{The Structure and Objectives of the VET Teacher Study Program at the Rostock's Institute for Vocational Education}

The study for the teaching profession at vocational schools takes place as a six-year Bachelor-Master study standardized by federal rules in Germany and is divided into three essential subjects: the professional subject (agriculture, metal technology, information technology etc.), a second general educational subject (German, mathematics, English etc.) and studies in vocational education and educational science, to which the TCI seminar belongs. Most students at the University of Rostock in the study programme for vocational teachers already have vocational training in the dual system or, if their professional experience lies in health or social work, have full-time school-based vocational training and work experience in addition.

The lecturers at the Institute for Vocational Education at the University of Rostock share the concept of critical vocational education and have increasingly oriented the individual modules and courses systematically towards the common goal of encouraging and empowering students to critically shape vocational education in the context of the development of their studies. This is based on the tradition of critical theory as described in chapter 2 in this article. Of particular importance here was a two-day retreat in March 2017, at which this mission statement and the competencies associated with it were systematized and assigned to individual modules in a second step in key areas (an approach based on professional and curriculum development within the framework of reorganization procedures, as developed and implemented by the author and others at the Federal Institute for Vocational Education and Training).

After an individual brainstorming session, goals of vocational school teacher training in Rostock were first compiled and then clustered with regard to the main categories of knowledge, ability and attitude. This gave rise to the vision of the characteristics of ideal graduates in the degree programme and the abilities, skills, attitudes and knowledge associated with them. Examples of this are: 
Skills and abilities: You can...

- organise participative teaching and conduct research into teaching

- support young people individually in their development process

- plan, implement and reflect on projects

- take care of yourself and shape your own competence development

- develop cooperation and moderating discussion situations

- argument your own thoughts

Knowledge: You have knowledge of...

- Vocational training facts and where to find them

- Paradigms of vocational Bildung

- Theories of vocational education and educational science

- Systemic contexts and their emergence

- Analysis of own experiences and self-reflection

Attitudes: You have willingness to practice...

- Tolerance and solidarity

- Transparency

- Authenticity and closeness

- Assumption of responsibility

- courageous action

- Curiosity and openness (inquiring attitude)

The module "Introduction to Vocational Education" consists of a lecture that provides an insight into the structures of vocational education and the scientific discipline of vocational education, its historical development, central concepts and specific topics such as youth, law, didactics and socialisation. Social exclusion is being addressed and other forms of vocational training are already being made visible in other countries. This lecture is accompanied by a seminar on the history of vocational education and training in which the specific situation of each historical epoch is worked out by the students on the basis of source texts in addition to a short lecture impulse. This makes it clear that 
the vocational training system is involved in a social development in the area of tension between the educational and economic systems, over which the respective form of social rule exerts a massive influence, as the significance of craftsmanship in the Middle Ages and the comparison of structures in National Socialism and in the GDR make clear. At the same time, the students gain initial experience in working with sources, recognize the different representations and interests in an epoch, depending on the background of the respective authorship, and practice their own arguments. History and vocational training are thus experienced as shape able, which do not develop naturally, but are influenced by people.

In the following academic year, terms in particular will be deepened and system structures will be analysed in greater depth. By writing an independent essay on key basic concepts of vocational education and training, independent opinion-forming and its argumentative presentation will be further developed. At the same time, the module on methodology and didactics introduces different forms of subject-oriented teaching and learning, is coupled with a company excursion and introduces the basics of the learning field approach, which prepares for the first orientation internship with a school and extracurricular part. Embedded in this module, an intensive examination of one's own individual development and the possibility of creating lively participative classroom design takes place.

\section{2 "Leading Yourself and Groups"- Concept and Practice of the TCI Seminar}

The theme centered Interaction seminar open space for intensive biographical self-reflection with regard to one's own social contexts, conscious and unconscious role models and experiences of leadership. Different creative methods of bodywork, sculptural design and painting of pictures as well as lively interaction between the participants are used. This includes an introduction to the theoretical principles and interrelationships of the TCI as well as to the rules and models of the method. At the same time, the students try out their first topic-centred leadership situations on topics which they select themselves and which have to do with their immediate life situation. They receive mutual feedback on these. The topic-centered interaction (Langmaack, 2004) serves as methodical and ethical.

The seminar begins with an introduction to the method and an orientation of the participants to the form of encounter in the seminar in the form of a circle of chairs, which makes it much easier to meet openly and to perceive all participants at the same time. This is followed by the first thematic lecture, which makes it clear that the individual is the starting point and goal of every pedagogical process. Here, the first self-reflection of individuals takes place, who realize their relationships to other people and groups and reflect on the question: "What is important to me in my current and future educational work!"

Following this individual reflection, which is accompanied by a pictorial representation, the participants hold a two-way discussion and then introduce themselves to each other in the group's plenum. 
The two subsequent seminar units are dedicated to the "we" and the "topic". Here it becomes clear which possibilities are available to the leaders to promote a lively and authentic togetherness in groups and which decisive role the right formulation of topics play. The lessons are overwritten with "We are not a mass - We get to know interactions and forms and rules of encounter in the TCI" and "A successful topic leads and connects". In the latter topic, participants practice formulating topics based on self-selected content inspired by the selection of objects with which something connects. The intensive contact to the own feeling is supported again and again by body-oriented meditations.

Before a block event takes place in which some of the participants test themselves in their own management on a self-chosen topic, they learn structural and planning aids that help to observe the balance of the triangle in the Globe and also support successful planning in terms of time. The students are individually supported in the preparation and the concept is discussed and further developed with the seminar leader.

An integral part of the block event is a seminar unit with the topic: "We are on the way to good leadership". This unit begins with the individual conquest of the space in which the seminar takes place in which each individual is invited to assume different positions in the space. Students sit under the tables, step onto the table, walk into a corner of the room or sit on a windowsill. This is followed by a partner exercise in which the couples, connected by long wooden sticks held by gentle pressure between their open hands, guide each other through the room without speaking to each other. The experience of one's own leadership is now extended to that of mutual guidance and the experience that the more the individual is aware of where he wants to go and at the same time perceives what his counterpart wants. Leadership is experienced as a balancing interplay of give and take. In small groups formed afterwards, the participants exchange ideas about factors of good leadership and are then asked to build a sculpture on the topic of "Good Leadership" based on a collection of objects, which is then presented to the entire group in the form of a museum tour. The unit concludes with a brief exchange in the circle of chairs on commonalities and differences in the sculptures and reflections.

Examples of topics developed by the students themselves are: "My fears and dealing with change", "Making small things out of big obstacles", "I am nature, what does nature mean to me", "Examination anxiety in my studies - how do I face the challenges", "What is a successful and healthy life for us?"

Since not all students can carry out an independent unit within the framework of the seminar, most develop a seminar concept lasting several days in the form of a paper and reflect on the potential of the TCI at the end of this work.

The feedback on the seminar is very positive and many students say that for the first time they had a situation in which they could reflect on themselves and their future work. They are also surprised at how easy it can be to lead a teaching unit if they build on the potential of the group involved and involve this more in the teaching process. But there were also two participants so far, who after the seminar recognized for themselves that the educational work does not suit them and decided on another further career.

Since we have placed this seminar specifically in the early stage of the study in order to positively support the group process of the respective beginner students, we are also interested in the effect of the seminar on the individuals and the interaction in the group 
afterwards. So far, we have observed a significant change in the number of participants with the lecturers and a constructive change in the atmosphere, but will not begin until this semester with a systematic survey of students with regard to the expected effects, based on scales from Rauner's studies on occupational identity (2017, p. 940 ff.) and Deci and Ryan on self-determination theory (1993).

\section{Summary and Outlook - The Task of Educational Science Teaching at Universities}

The article started with a change in the demands on employees with regard to their social competence without at the same time pointing out the manifoldly increased demands for self-control that accompany the separation of the individual from traditional life contexts, increasing mobility and a variety of conceivable life plans that we can record in the developed nations (Schapfel-Kaiser, 1998). The description of these changes was accompanied by the elaboration of the field of tension between vocational and general education (if general education exists and has ever existed in a purposeless form). To underline this field of tension, the considerations of critical education theory in the tradition of the Frankfurt School were received with central statements and it was made clear that the claim to Bildung can be indivisible and can therefore also be brought to bear for vocational education. Teachers at vocational schools in Germany are persons employed by the state who are committed to the idea of Bildung and the goal of supporting personal development. To show vocational teacher students the possibility of a democratic and lively learning process TCI was described with its roots and main characteristics of the concept. How this concept is embedded and practical realized at the University of Rostock is the content of the last chapter.

Vocational teachers have to critically reflect on their professional actions against the background of economic and social development as well as their individual biographies and need not only cognitively acquired knowledge but also methodological and didactic competence paired with a personality who courageously goes into contradictions to generalized behaviours. This, coupled with the reflected experience of domination-free communication and participatory learning within the framework of university studies, which can create a distance to a given social reality, enables them from collectively developed goals to become critical formers of their teaching but also of the entire vocational training.

"Insofar as the search for truth creates a spiritually determined community in which, according to Gustav Landauer, 'the generally human and the individual unique' expresses itself, in which it witnesses a connection that does not want the life-fulfilling and future-open possibility to perish in nitdurft, numbness, rape and the loss of human dignity, it becomes the commitment of the university teacher to defend the shaping social principle also in it. It is his task to keep open the realization of enlightened reason in the contradictions of the world also as a common possibility" (Heydorn, 1980, p. 74).

In such an understanding, the reflection of human history as well as the seizure of the given possibilities in vocational education and university teaching, paired with the 
courage for authentic interaction with the students, becomes one main task of the vocational educational university teacher. Self-reflective awareness and authentic vulnerability at the same time can prevent and encourage technocratic understanding and implementation of vocational education and training. The principle of hope for human coexistence and learning must also be maintained in vocational training.

\section{References}

Amman, I. (1993). Das Dreieck in der Kugel. Spirituelle Aspekte der TZI. In: Löhmer, C. \& Standhardt, R. (Hrsg.): TZI. Pädagogisch-therapeutische Gruppenarbeit nach Ruth C. Cohn. Stuttgart: Klett-Cotta, 144-174.

Cohn, R. (1969). From Couch to circle to community. Beginnings of the Theme-centered Interactional Method. In: Group therapy today. Ruitenbeeck, New York, 1969. Photocopy of typrewritten manuscript, 13, open access: http://www.ruth-cohninstitut-rw.de/tl_files/content/zentraleinhalte/Originaltexte\%20RC\%20-\%20engl/5_ From_couch_to_circle_to_community.pdf

Cohn, R. (1990). Zu wissen das wir zählen. Gedichte. Bern: Zytglogge.

Cohn, R. (1992). I'm not a Gura! Interview between Ruth Cohn and Horst Heidbrink. In: "Group Dynamics" Vol. 23, Issue 3, 1992, 315-325.

Cohn, R., \& Farau, A. (1984). Gelebte Geschichte der Psychotherapie. Zwei Perspektiven. Stuttgart: Klett.

Cort, P., Härkönen, A., \& Volmari, K. (2004). Professionalisation of VET teachers for the future. Luxemburg: CEDEFOP.

Decy, E.L., \& Ryan, R.M. (1993). Die Selbstbestimmungstheorie der Motivation und ihre Bedeutung für die Pädagogik. In: Zeitschrift für Pädagogik. Jg. 39, H. 2, 223-238.

Engelen-Kefer, U. (1976). Humanisation of work in the Federal Republik of Germany - A labour-oriented approach. In: International labour review. Vol 113, No. 2, $227-241$.

European Commission. (2008). Explaining the European Framework for Lifelong Learning. Luxembourg.

Heydorn, H.J. (1962). Vom Engagement des Hochschullehrers. In: Heydorn, H.J.: Zur bürgerlichen Bildung. Anspruch und Wirklichkeit. Bildungstheoretische Schriften Bd. 1. Frankfurt: Syndikat, 72-74.

Heydorn, H.-J. (1970). Über den Widerspruch von Bildung und Herrschaft, Frankfurt: Europäische Verlagsanstalt.

Heydorn, H. J. (1973). Zum Widerspruch im Bildungsproze. In: Heydorn, H.J.: Ungleichheit für alle. Zur Neufassung des Bildungsbegriffs, Bildungstheoretische Schriften, Band 3, Frankfurt: Syndikat, 269-281.

Horkheimer, M. (1952). Begriff der Bildung. In: Sozialphilosophische Studien. Aufsätze, Reden und Vorträge 1930-1972, hrsg. v. Werner Brede, Frankfurt: dtv S. 163-172.

Horkheimer, M. (1953). Fragen des Hochschulunterrichts. In: Sozialphilosophische Studien. Aufsätze, Reden und Vorträge 1930-1972, hrsg. V. Werner Brede, Frankfurt: dtv 1972, 172-187. 
Gamm, H. J. (1983). Materialistisches Denken und pädagogisches Handeln, Frankfurt: Klett.

Kaiser, F. (2008). "Ich teil' mich da so rein" - Phänomene der Zeit in Berufen. Ein Beitrag zur kritisch-subjektorientierten Berufsbildung. In: Fahauer, U., Münk, D., Paul-Kohlhoff, A. (Hrsg.): Berufspädagogische Forschung in sozialer Verantwortung. Festschrift für Josef Rützel zum 65. Geburtstag. Stuttgart: Steiner, 181-196.

Kaiser, F. (2016). Berufliche Bildung und Emanzipation. Heydorns Impulse für eine kritische Berufsbildungstheorie sowie Stolpersteine aus eigener berufspädagogische Sicht. In: Ragutt, F., \& Kaiser, F. (Hrsg.): Menschlichkeit der Bildung. Heydorns Bildungsphilosophie im Spannungsfeld von Subjekt, Arbeit und Beruf. Paderborn: Schoeningh.

Koneffke, G. (1987). Widersprüche im frühbürgerlichen Bildungsbegriff. In: Drechsel, R.; Gerds, P.; Körber, K.; Twisselmann, J. (Hrsg.): Ende der Aufklärung? Zur Aktualität einer Theorie der Bildung. Bremen: Universität Bremen, 131-148.

Kroeger, M. (1993). Anthropologische Grundannahmen der TZI. In: Löhmer, Cornelia; Standhardt, Rüdiger (Hrsg.): TZI. Pädagogisch-therapeutische Gruppenarbeit nach Ruth C. Cohn. Stuttgart: Klett-Cotta, 93-124.

Langmaack, B. (1991). Themenzentrierte Interaktion. Einführende Texte rund ums Dreieck. Weinheim: Psychologische Verlags Union.

Matzdorf, P., \& Cohn, R. (1992). Das Konzept der Themenzentrierten Interaktion. In: Löhmer, Cornelia; Standhardt, Rüdiger (Hrsg.): TZI. Pädagogisch-therapeutische Gruppenarbeit nach Ruth C. Cohn. Stuttgart: Klett, 39-92.

Paffrath, H. F. (1992). Die Wendung aufs Subjekt. Pädagogische Perspektiven im Werk Theodor W. Adornos. Weinheim: Beltz.

Petersen, W., \& Rauner, F. (1995). Education and training for the human centred factory. Bremen: ITB.

Rauner, F. (2017). Grundlagen beruflicher Bildung. Bielefeld: W. Bertelsmann.

Rubner, A. (2017). The Psychoanalytic foundation of TCI. In: Schneider-Landloff, M. et. al. (edit): Handbook of Theme Centered Interaction. Göttingen / Bristol: V\&R, retrieved from: http://www.v-r.de/_uploads_media/files/eb_9783666451904_102307.pdf, 31-34.

Satre, J.-P. (1961). Ist der Existentialismus ein Humanismus? Drei Essays. Berlin: Ullstein.

Schapfel-Kaiser, F. (1997). Themenzentrierte Interaktion als Gestaltungsinstrument und Forschungshilfe für berufliche Bildungsprozesse in aktuellen Wandlungsprozessen. Chancen und Grenzen eines pädagogisch-therapeutischen Zugangs im Zusammenhang mit einem betrieblichen Modellversuch. In: Zeitschrift für Berufs- und Wirtschaftspädagogik. 93. Bd. H. 5, 500-520.

Schapfel-Kaiser, F. (1998). Vom verstreuten Treibholz zum Flo. Lernen an und mit der Biographie in der beruflichen Bildung. Ein Aspekt kritisch-subjektorientierter Berufspädagogik. In: Rützel, J \& Sesink, W. (Hrsg.): Jahrbuch für Pädagogik 1998 Bildung nach dem Zeitalter der groen Industrie. Frankfurt: Lang, 127-148.

Schapfel-Kaiser, F. (2006). Wirtschaft im Widerspruch zu neoliberaler (Ver)Wert(ungs) Herrschaft. Das Unternehmen Hoppmann und die Stiftung Demokratie im Alltag. 
In: Klute, J. \& Schneider, H.-U. (Hrsg.): Auf dem Weg der Gerechtigkeit ist Leben. Sozialethische Anmerkungen zur sozialen Gerechtigkeit heute. Festschrift zum 65. Geburtstag von Wolfgang Belitz. Münster: LIT-Verlag, 199-214.

Schapfel-Kaiser, F. (2014). TCI and Vocational Training. In: Schneider-Landloff, M. et. al. (edit): Handbook of Theme Centered Interaction. Göttingen / Bristol: V\&R, retrieved from: http://www.v-r.de/_uploads_media/files/eb_9783666451904_102307.pdf, $312-315$.

Schneider-Landloff, M., Spielmann, J., \& Zitterbarth, W. (2017). Handbook of Theme Centered Interaction. Göttingen / Bristol: V\&R, retrieved from: http://www.vr.de/_uploads_media/files/e b_9783666451904_102307.pdf

Schröder, J. (2009). Besinnung in flexiblen Zeiten. Leibliche Perspektiven auf moderne Zeiten. Wiesbaden.

Stratmann, K. W. (1993). Die gewerbliche Lehrlingserziehung in Deutschland. Bd. 1: Berufserziehung in der ständischen Gesellschaft. Frankfurt.

Streumer, J., \& Bjorkquist, D. C. (1998). Moving Beyond Traditional Vocational Education and Training. In: Nijhof, W.J. \& Streumer, J.H. (Eds.): Key Qualifications in Work and Education, Dordrecht, Boston, London: Kluwer Academic Publishers, 247-263.

Kaiser, F., Krugmann, S. (edit.) (2017). Social Dimensions and Participation in Vocational Education. Proceedings of the 2nd Crossing boundaries in VET Conference. Rostock 2017. Available from: https://www.researchgate.net/publication/320083 654_Social_Dimensions_and_Participation_in_Vocational_Education_Proceedings_of_th e_2nd_Crossing_boundaries_in_VET_Conference_Rostock_2017 [accessed Apr 29 2018]. WILL-Schweiz. (2004). Lehrgang Ausbilder/in auf der Grundlage der TZI. St. Gallen: Werkstatt Institut für lebendiges Lernen (WILL).

Zitterbarth, W. (2017). TCI and Philosophy. In: Schneider-Landloff, M. et. al. (edit): Handbook of Theme Centered Interaction. Göttingen / Bristol: V\&R, retrieved from: http://www.v-r.de/_uploads_media/files/eb_9783666451904_102307.pdf, 4549.

\section{Biographical Notes}

Dr Franz Kaiser is professor and founding director at the Institue for Vocational Education, University of Rostock in Germany. His lectures and research focus on vocational curricula and training regulations development, group dynamics, VET teachers, international research in VET, time concepts and the critical theory of 'Bildung' in VET. 